\title{
PENGARUH BAURAN PEMASARAN DAN KUALITAS PELAYANAN TERHADAP KEPUTUSAN PEMBELIAN PRODUK PAKAIAN DI BARATA KOTA BIMA
}

\author{
Erick Dala Oscar ${ }^{1}$, Irma Mardian ${ }^{2}$ \\ Sekolah Tinggi Ilmu Ekonomi Bima ${ }^{1,2}$ \\ Erickdalaoscar17@gmail.com ${ }^{1}$, irmamardian@gmail.com ${ }^{2}$
}

\begin{abstract}
This research is an associative research, namely research that aims to determine the influence of the marketing mix and service quality partially and simultaneously on purchasing decisions for clothing products. This research was conducted in Barata, Bima city. The research instrument used is a questionnaire containing a number of questions about the marketing mix, service quality and purchasing decisions for clothing products. The population used is all consumers who buy clothing products in Barata, Bima city, the population is unknown (population unknown). Therefore, to determine the number of samples using the unknown population formula in order to obtain 96 respondents. The sampling technique used is accidental sampling, namely Barata consumers who happen to meet with researchers can be used as samples tailored to the needs of researchers. Data collection techniques used in this study are: observation, heritage studies and documentation. The data analysis techniques used are validity, reliability, classical assumption test, multiple linear regression, multiple correlation coefficient, $t$ test (partial) and simultaneous $f$ test. The results of this study indicate that the marketing mix partially has no effect on purchasing decisions for clothing products in Barata, service quality partially affects purchasing decisions for clothing products in Barata, but the marketing mix and service quality simultaneously affect purchasing decisions for clothing products in Barata.
\end{abstract}

Keyword : marketing mix; service quality; buying decision

\section{PENDAHULUAN}

\section{Latar Belakang}

Departement store merupakan salah satu industri ritel yang kini semakin diminati oleh konsumen untuk berbelanja berbagai kebutuhan sandang. Hal tersebut dikarenakan department store memiliki kelebihan di mana konsumen dapat leluasa memilih barang-barang sesuai dengan selera dan kebutuhannya. Saat ini, department store dihadapkan dengan banyaknya tantangan seiring dengan semakin banyaknya pesaing dan semakin gencarnya online shop dengan berbagai keunggulannya. Kedua hal ini dinilai sebagai penyebab berkurangnya pengunjung departement store.

Salah satunya Department store yang ada di Bima seperti Barata memiliki kelebihan dimana konsumen dapat leluasa memilih fashion sesuai selera dan kebutuhannya. Akan tetapi semakin berkembangnya teknologi Barata dihadapkan dengan banyaknya tantangan. Seiring dengan semakin banyaknya pesaing dan semakin gencarnya online shop lebih murah dan lebih banyak pilihan model terkini. Hal ini dinilai sebagai penyebab berkurangnya pengunjung Barata.

Oleh Karena itu untuk dapat berkembang, Barata harus mampu meningkatkan penjualan yang merupakan ujung tombak bisnis, dengan kata lain Barata harus 
memperhatikan aspek-aspek bauran pemasaran. Hal ini dikarenakan sebagai salah satu usaha terintegritas membuat produk untuk memenuhi kebutuhan konsumen. Selain itu pemasaran juga berperan memperkenalkan produk tersebut kepada konsumen agar konsumen bisa memenuhi kebutuhan sesuai keinginannya.

Berdasarkan observasi yang dilakukan peneliti, bauran pemasaran yang dilakukan oleh Barata belum mampu meningkatkan keputusan konsumen untuk membeli produk pakaian. Seperti misalnya harga yang ditawarkan lebih mahal dari tempat lain, kualitas bahan pakaian tidak sesuai dengan harapan konsumen serta promosi seperti diskon sale dll, yang di lakukan oleh Barata belum sepenuhnya mampu membuat konsumen membeli produk pakaian di Barata. Hal inilah yang membuat barata belum memaksimalkan promosi produk tersebut.

Selain bauran pemasaran, kualitas pelayanan yang baik juga mempengaruhi keputusan pembelian produk fashion pakaian di Barata. Barata juga dihadapkan dengan banyaknya tantangan seiring dengan semakin banyaknya pesaing dibidang yang sama.

Seperti halnya kualiatas pelayanan di Barata masih kurang bagus sehingga masih ada beberapa konsumen mengeluh pelayanan yang diberikan oleh karyawan Barata diantaranya terlambat atau sering menunda menangani permintaan konsumen, kurang sigap menangani keluhan konsumen dalam membeli produk yang dibeli konsumen. Karyawan Barata sering tidak mengetahui informasi produk pakaian sehingga membuat konsumen enggan membeli. Padahal pelayanan yang baik akan meningkatkan kepuasan konsumen dalam membeli produk pakaian di Barata Kota Bima.

Berdasarkan latar belakang yang dipaparkan diatas peneliti tertarik melakukan penelitian tentang "Pengaruh Bauran Pemasaran Dan Kualitas Pelayanan Terhadap Keputusan Pembelian Produk Pakaian Di Barata Kota Bima”.

\section{Rumusan Masalah}

Berdasarkan pendeskripsian latar belakang diatas maka dapat dirumuskan masalah yang akan diteliti sebagai berikut :

1. Adakah pengaruh bauran pemasaran terhadap keputusan pembelian produk pakaian di Barata Kota Bima?

2. Adakah pengaruh kualitas pelayanan terhadap keputusan pembelian produk pakaian di Barata Kota Bima?

3. Adakah pengaruh bauran pemasaran dan kualitas pelayanan terhadap keputusan pembelian produk pakaian di Barata Kota Bima?

\section{KAJIAN LETERATUR}

\section{Bauran Pemasaran}

Menurut Sumarmi dan Soepriharto dalam Dewi dan Sutanto (2018), Bauran pemasaran adalah kombinasi dari variabel atau kegiatan yang merupakan inti dari system pemasaran yaitu produk, harga, promosi dan distribusi. Dengan kata lain definisi bauran pemasaran adalah kumpulan dari variabel yang dapat digunakan oleh perusahaan untuk dapat mempengaruhi tanggapan konsumen.

Bauran pemasaran merupakan seperangkat alat pemasaran terkontrol yang dipadukan oleh perusahaan untuk menghasilkan respon yang diinginkan pasar tertuju (Kotler dan Armstrong, 2012). Komponen bauran pemasaran dikenal dengan istilah 4P, yaitu produk (product), harga (price), tempat (place), dan promosi (promotion). 
Bauran pemasaran merupakan istilah yang dipakai untuk menjelaskan kombinasi empat besar sebuah organisasi. keempat unsur tersebut adalah penawaran produk,struktur harga kegiatan promosi dan sistem distribusi.

Menurut Ferdinad dalam Dewi dan Sutanto (2018) bauran pemasaran dapat didefinisikan melalui indikator sebagai berikut :

a. Produk merupakan segala sesuatu yang dapat ditawarkan produsen untuk diperhatikan, diminati, dicari, dibeli, digunakan atau dikonsumsi dipasar sebagai pemenuhan atau keinginan pasar yang bersangkutan.

b. Promosi adalah suatu komunikasi dari penjual dan pembeli yang berasal dari informasi tepat yang bertujuan untuk merubah sikap dan tingkah laku serta pembeli yang tadinya tidak mengenal menjadi mengenal sehingga menjadi pembeli dan tetap mengingat produk tersebut.

c. Harga dapat didefinisikan sebagai alat tukar dan merupakan jumlah uang diperlukan sebagai penukar berbagai kombinasi produk dan jasa.

d. Lokasi yaitu tempat yang strategis menyenangkan dan efisien yang digunakan untuk menarik minat konsumen.

\section{Kualitas pelayanan}

Menurut Kotler dalam Ridwan dan Fure (2015) Pelayanan adalah setiap kegiatan atau manfaat yang ditawarkan oleh suatu pihak pada pihak lain dan pada dasarnya tidak berwujud, serta tidak menghasilkan kepemilikan sesuatu.

Sedangkan menurut Parasuraman, et al dalam Ridwan (2011), Kualitas pelayanan merupakan sikap yang berhubungan dengan keunggulan jasa pelayanan atau pertimbangan konsumen tentang kelebihan suatu perusahaan. Menurut Parasuraman dalam Fure dkk (2015) Indikator kualitas pelayanan terdapat lima dimensi sebagai berikut:

a. Kendala (reliability) yaitu kemampuan perusahaan untuk memberikan pelayanan sesuai yang dijanjikan dengan segera, akurat dan dapat dipercaya, harus sesuai dengan harapan konsumen.

b. Daya tanggap (responsiviess) yaitu kemampuan untuk membantu dan memberikan pelayananyang cepat dan tepat kepada konsumen dengan penyampaian informasi yang jelas.

c. Jaminan (assurance) yaitu pengetahuan, kesopan santunan, dan kemampuan para pegawai perusahaan untuk menumbuhkan rasa percaya konsumen kepada perusahaan. Terdiri dari pengetahuan, kopetensi, kesopanan dan sifat dapat dipercaya dimiliki para karyawan.

d. Empati (emphaty) yaitu memberikan perhatian, tulus dan bersifat individual atau pribadi kepada konsumen dengan berupaya memahami keinginan konsumen dimana suatu perusahaan diharapkan memiliki pengertian dan pengetahuan tentang konsumen serta memahami konsumen.

e. Bukti fisik (tangible) yaitu kemampuan perusahaan menunjukan eksitensinya meliputi fasilitas fisik (grdung, gudang dll) teknologi ( peralatan dan perlengkapan yang dipergunakan) serta penampilan pegawai.

\section{Keputusan Pembelian}

Menurut Setiadi (2012) pengambilan keputusan yang diambil seseorang dapat disebut sebagai sesuatu pemecahan masalah. Dalam proses pengambilan keputusan konsumen memiliki sasaran atau perilaku yang ingin dicapai atau dipuaskan selanjutnya konsumen membuat keputusan prilaku mana yang ingin dilakukan untuk mencapai sasaran tersebut. Menurut Kotler dan Keller (2016:144) 
Keputusan pembelian adalah suatu tindakan yang dilakukan konsumen untuk mau membeli atau tidak terhadap suatu produk yang ditawarkan penjual.

Menurut Kotler dan Amstrong (2012), Konsep keputusan pembelian yang dilakukan oleh para konsumen melalui 5 tahap, yaitu :

a. Pengenalan Kebutuhan

Proses pembelian dimulai saat konsumen mengenali sebuah masalah atau kebutuhan. Pemasar perlu mengidentifikasi rangsangan yang paling sering membangkitkan minat akan suatu jenis produk sehingga dapat mengembangkan strategi pemasaran.

b. Pencarian Informasi

Konsumen yang terangsang kebutuhannya akan terdorong untuk mencari informasi yang lebih banyak, dan dapat dibagi ke dalam dua level rangsangan. Situasi pencarian informasi yang lebih ringan dinamakan penguatan perhatian. Pada level ini, orang hanya sekedar lebih peka terhadap informasi produk. Pada level selanjutnya, orang mungkin mulai aktif mencari informasi lebih banyak seperti mencari bahan bacaan, menelpon teman, dan mengunjungi toko untuk mempelajari produk tertentu.

c. Evaluasi Alternatif

Evaluasi alternatif adalah proses mengevaluasi produk dan merek, dan memilihnya sesuai dengan yang diinginkan konsumen. Pada proses evaluasi alternatif, konsumen membandingkan berbagai pilihan yang dapat memecahkan masalah yang dihadapinya. Evaluasi alternatif muncul karena banyaknya alternatif pilihan, dan disini konsumen akan memilih merek yang akan memberikan manfaat yang diharapkannya.

d. Keputusan pembelian

Dalam tahap evaluasi konsumen membentuk preferensi antar merek dalam kumpulan pilihan. Konsumen juga membentuk maksud untuk membeli merek yang disukai. Dalam melaksanakan maksud pembelian, konsumen dapat membentuk lima sub keputusan: merek, penyalur, kuantitas, waktu dan metode pembayaran.

e. Perilaku pasca pembelian

Kepuasan merupakan fungsi kedekatan antara harapan dan kinerja anggapan produk. Jika kinerja tidak memenuhi harapan, konsumen kecewa. Jika memenuhi harapan maka konsumen puas. Perasaan ini menentukan apakah pelanggan membeli produk kembali dan menjadi pelanggan setia.

\section{Hipotesis Penelitian}

Hipotesis merupakan jawaban sementara terhadap rumusan masalah penelitian, dimana rumusan masalah penelitian telah dinyatakan dalam bentuk kalimat pernyataan. Dikatakan sementara karena jawaban yang diberikan baru berdasarkan pada teori yang relevan, belum didasarkan pada fakta-fakta empiris yang diperoleh melalui pengumpulan data, (Sugiyono, 2016)

Bedasarkan latar belakang, rumusan masalah,tujuan penelitian serta tinjauan pustaka diatas maka hipotesis yang akan di uji dalam penelitian ini adalah sebagai berikut:

H1 :Terdapat pengaruh bauran pemasaran Terhadap keputusan pembelia produk pakaian dibarata kota bima

H2 :Terdapat pengaruh kualitas pelayanan Terhadap keputusan pembelian produk pakaian dibarata kota bima

H3 :Terdapat pengaruh bauran pemasaran dan kualitas pelayanan Terhadap keputusan pembelian produk pakaian dibarata di barata 
Kota bima.

\section{METODE}

\section{Jenis Penelitian.}

Dalam penelitian ini digunakan jenis penelitian Asosiatif yaitu suatu penelitian yang bersifat mengetahui hubungan antara dua variabel atau lebih dan mempunyai tingkat yang lebih bila di bandingkan dengan penelitian deskriptif dan komparatif (Sugiyono, 2016).

\section{Populasi, Sampel Penelitian, Dan Sampling Penelitian}

Populasi adalah wilayah generalisasi yang terdiri atas obyek / subyek yang mempunyai kualitas dan karakteristik tertentu yang diterapkan oleh peneliti untuk dipelajari dan ditarik kesimpulan. (Sugiyono 2014). Populasi yang digunakan dalam penelitian ini yaitu seluruh konsumen yang pernah berbelanja pakaian di barata.

Sampel penelitian Sugiyono (2014) Mengungkapkan bahwa sampel adalah bagian dari jumlah dan karakteristik yang dimiliki oleh populasi tersebut. Dikarenakan populasinya tidak dikatahui secara pasti, menurut Riduwan (2015), untuk menentukan jumlah sampel dalam populasi yang tidak diketahui maka digunakan rumus cochran dan dan diperoleh sampel sebanyak 96\% orang.

Rumus uknow population :

$$
n_{0}=\frac{z^{2} p q}{e^{2}}=\frac{(1,96)^{2}(0,5)(0,5)}{(0,1)^{2}}=96 \text { orang }
$$

Teknik pengambilan Sampel dilakukan Teknik accidental sampling yaitu konsumen Barata yang secara kebetulan bertemu dengan peneliti dapat digunakan sebagai sample disuaikan dengan kebutuhan peneliti.

\section{Instrument penelitian dan tehnik pengumpulan data}

Instrumen penelitian adalah suatu alat yang di gunakan untuk mengukur fenomena alam maupun sosial yang diamati kuesioner (Sugiyono,2008). Instrumen penelitian yang digunakan yaitu dalam penelitian ini yaitu Kuensioner dengan menggunakan skala likert . Teknik pengumpulan data yang di gunakan dalam penelitian ini yaitu : observasi, study pusaka dan dokumentasi. Teknik analisa data yang di gunakan yaitu uji validitas ,reliabilitas , uji asumsi klasik ,regresi linear berganda ,kofisien kolerasi berganda, uji $\mathrm{t}$ (parsial) dan uji f simultan.

\section{HASIL DAN DISKUSI}

\section{Uji Validitas}

Uji Validitas Kuensioner Untuk Variabel Bauran Pemasaran, Kualitas Pelayanan Dan Keputusan Pembelian Dalam Penelitian Ini Dilakukan Kepada 96 Responden Dengan Nilai R Hitung $>0.30$ Sehingga Dapat Disimpulkan Variabel Penelitian Ini Valid.

\section{Uji Reabilitas}

Nilai Cronbach Alpha Untuk Variabel X1 Sebesar 0,734 Sehingga Dapat Disimpulkan Bahwa Instrument Yang Digunakan Pada Penelitian Ini Merupakan 
Instrument Yang Reliable.. Nilai Cronbach Alpha Untuk Variabel X2 Sebesar 0,750 Sehingga Dapat Disimpulkan Bahwa Instrument Yang Digunakan Pada Penelitian Ini Merupakan Instrument Yang Reliable. Nilai Cronbach Alpha Untuk Variabel Y Sebesar 0,749 Sehingga Dapat Disimpulkan Bahwa Instrument Yang Digunakan Pada Penelitian Ini Merupakan Instrument Yang Reliable.

\section{Uji Asumsi Klasik}

\section{Tabel 1. Uji Normalitas}

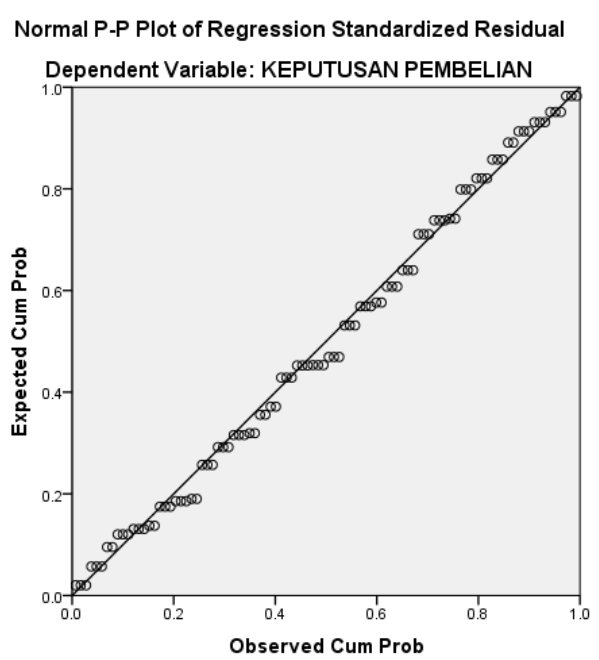

Sumber: Data diolah, 2021

Dari data gambar diatas dapat dijelaskan bahwa data menyebar disekitar garis diagonal dan mengikuti arah garis diagonal, maka dapat disimpulkan bahwa model regresi memenuhi asumsi normalitas.

Tabel 2. Uji Autokorelasi

\begin{tabular}{|c|c|c|c|c|c|}
\hline \multicolumn{6}{|c|}{ Model Summary ${ }^{\mathbf{b}}$} \\
\hline Model & $\mathrm{R}$ & R Square & $\begin{array}{l}\text { Adjusted R } \\
\text { Square }\end{array}$ & $\begin{array}{l}\text { Std. Error of the } \\
\text { Estimate }\end{array}$ & Durbin-Watson \\
\hline 1 & $.690^{\mathrm{a}}$ & .477 & .465 & 8.846 & 1.685 \\
\hline \multicolumn{6}{|c|}{ a. Predictors: (Constant), KUALITAS PELAYANAN, BAURAN PEMASARAN } \\
\hline \multicolumn{6}{|c|}{ b. Dependent Variable: KEPUTUSAN PEMBELIAN } \\
\hline
\end{tabular}

Sumber: Data diolah, 2021

Dari table diatas menunjukan angka Durbin-Watson sebesar 1,658. Angka tersebut berada diantara $1.6254<1,658<1,7103$, maka dapat disimpulkan bahwa model regresi diatas tidak terjadi masalah autokolerasi. Maka dari itu saya menggunakan uji runt test untuk mengatasi masalah autokolerasi tersebut. 
Tabel 3. Uji Heteroskedastisitas

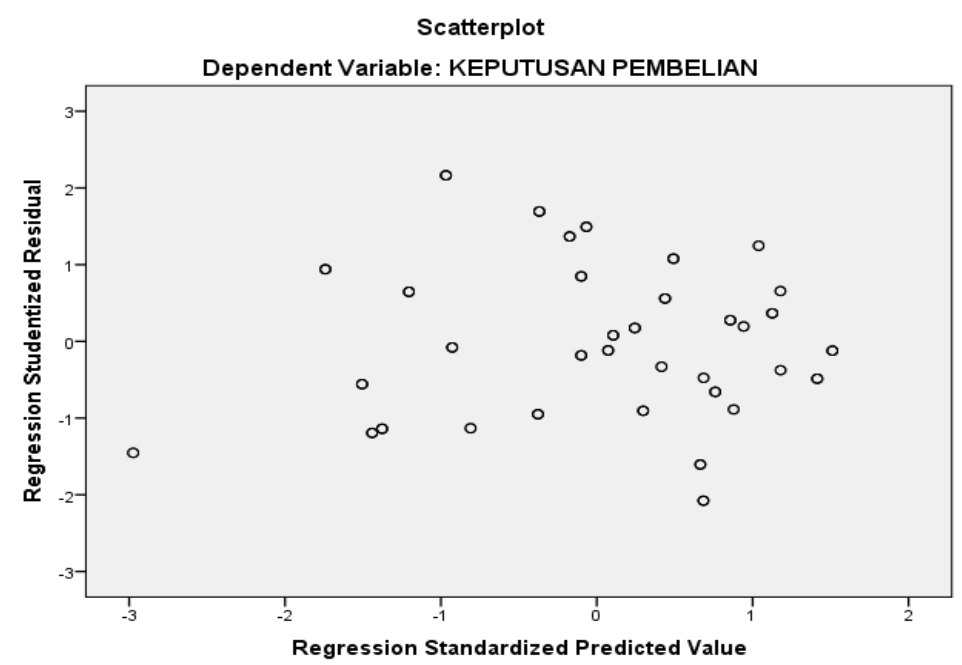

Sumber: Data diolah, 2021

Dari gambar diatas dapat diketahui bahwa tidak terjadi heterosdastisitas sebab tidak ada pola yang jelas serta titik-titik menyebar diatas dan diwabah angka 0 pada sumbu Y sehingga dapat dikatakan uji heteroskedastisitas terpenuhi.

Tabel 4. Uji Multikolinearitas

\begin{tabular}{|c|c|c|c|c|c|c|c|c|}
\hline \multicolumn{9}{|c|}{ Coefficients $^{\mathrm{a}}$} \\
\hline \multirow{2}{*}{\multicolumn{2}{|c|}{ Model }} & \multicolumn{2}{|c|}{$\begin{array}{l}\text { Unstandardized } \\
\text { Coefficients }\end{array}$} & \multirow{2}{*}{$\begin{array}{c}\text { Standard } \\
\text { ized } \\
\text { Coeffici } \\
\text { ents }\end{array}$} & \multirow[t]{2}{*}{$\mathrm{t}$} & \multirow[t]{2}{*}{ Sig. } & \multicolumn{2}{|c|}{$\begin{array}{c}\text { Collinearity } \\
\text { Statistics }\end{array}$} \\
\hline & & B & $\begin{array}{l}\text { Std. } \\
\text { Error }\end{array}$ & & & & $\begin{array}{l}\text { Toler } \\
\text { ance }\end{array}$ & VIF \\
\hline \multirow{3}{*}{1} & (Constant) & 15.467 & 5.725 & & $\begin{array}{r}2.70 \\
2 \\
\end{array}$ & .008 & & \\
\hline & $\begin{array}{l}\text { BAURAN } \\
\text { PEMASARAN }\end{array}$ & .089 & .119 & .066 & .745 & .458 & .718 & $\begin{array}{r}1.39 \\
3 \\
\end{array}$ \\
\hline & $\begin{array}{l}\text { KUALITAS } \\
\text { PELAYANAN }\end{array}$ & .628 & .085 & .653 & $\begin{array}{r}7.37 \\
8\end{array}$ & .000 & .718 & $\begin{array}{r}1.39 \\
3\end{array}$ \\
\hline
\end{tabular}

a. Dependent Variable: KEPUTUSAN PEMBELIAN

Sumber: Data diolah, 2021

Dari hasil uji multikolinearitas pada tabel diatas dapat diketahui nilai Tolerance $>$ 0,100 atau bauran pemasaran dan kualitas pelayanan 0,718 dan nilai $\mathrm{VIF}<10,00$ atau bauran pemasaran dan kualitas pelayanan 1,393 maka dapat disimpulkan bahwa tidak ada kejala multikolinearitas. 
Berdasarkan hasil pengujian dari tabel diatas dapat dibuat model persamaan regresi sebagai berikut :

$\mathrm{Y}=15.467+0,089 \mathrm{X} 1+0,628 \mathrm{X} 2$

Model persamaan regresi diatas menunjukan nilai konstanta $(\alpha)$ sebesar 15.467 hal ini berarti jika bauran pemasaran dan kualitas pelayanan bernilai 0, maka keputusan pembelian bernilai sebesar 15.467 dengan asumsi faktor lainnya bernilai tetap. Sedangkan hasil uji regresi linear berganda untuk variabel independen dapat dijelaskan sebagai berikut :

a. Nilai koefisien (B) untuk bauran pemasaran menunjukan angka yaitu 0,089 hal ini berarti setiap peningkatan 1 bauran pemasaran maka akan mengalami peningkatan keputusan pembelian sebesar 0,089 dengan asumsi faktor lain bernilai tetap.

b. Nilai koefisien (B) untuk kualitas pelayanan menunjukan angka yaitu 0,628 hal ini berarti setiap peningkatan 1 kualitas pelayanan, maka akan meningkat keputusan pembelian sebesar 0,628 dengan asumsi faktor lain bernilai tetap.

Tabel 5. Koefisien korelasi berganda

\begin{tabular}{|l|r|r|r|r|r|}
\hline \multicolumn{6}{|c|}{ Model Summary } \\
\hline Model & R & R Square & $\begin{array}{c}\text { Adjusted R } \\
\text { Square }\end{array}$ & $\begin{array}{c}\text { Std. Error of the } \\
\text { Estimate }\end{array}$ & Durbin-Watson \\
\hline 1 & $.690^{\mathrm{a}}$ & .477 & .465 & 8.846 & 1.685 \\
\hline
\end{tabular}

a. Predictors: (Constant), KUALITAS PELAYANAN, BAURAN PEMASARAN

b. Dependent Variable: KEPUTUSAN PEMBELIAN

Sumber: Data diolah, 2021

Dari table diatas, angka $\mathrm{R}$ sebesar 0,690 menunjukan bahwa korelasi atau hubungan antara variable dependen yaitu keputusan pembelian dengan 2 variabel independennya yaitu bauran pemasaran dan kualitas pelayanan.yaitu kuat.

Nilai R Square menunjukan angka sebesar 0,477. Hal ini berarti bahwa besar kemampuan ke dua variable independen terhadap variable dependen yang dapat dijelaskan oleh persamaan ini adalah sebesar $47.7 \%$ sedangkan sisanya sebesar $52,30 \%$ di sebabkan oleh factor-faktor lain yang tidak dimasukkan dalam penelitian ini.

Tabel 6. Uji t 2 pihak (Parsial)

\begin{tabular}{|c|c|c|c|c|c|c|c|c|}
\hline \multicolumn{9}{|c|}{ Coefficients $^{\mathbf{a}}$} \\
\hline \multirow{2}{*}{\multicolumn{2}{|c|}{ Model }} & \multicolumn{2}{|c|}{$\begin{array}{l}\text { Unstandardized } \\
\text { Coefficients }\end{array}$} & \multirow{2}{*}{$\begin{array}{c}\text { Standard } \\
\text { ized } \\
\text { Coeffici } \\
\text { ents } \\
\text { Beta }\end{array}$} & \multirow[t]{2}{*}{$\mathrm{t}$} & \multirow[t]{2}{*}{ Sig. } & \multicolumn{2}{|c|}{$\begin{array}{l}\text { Collinearity } \\
\text { Statistics }\end{array}$} \\
\hline & & B & $\begin{array}{l}\text { Std. } \\
\text { Error }\end{array}$ & & & & $\begin{array}{l}\text { Toler } \\
\text { ance }\end{array}$ & VIF \\
\hline \multirow{3}{*}{1} & (Constant) & 15.467 & 5.725 & & $\begin{array}{r}2.70 \\
2\end{array}$ & .008 & & \\
\hline & $\begin{array}{l}\text { BAURAN } \\
\text { PEMASARAN }\end{array}$ & .089 & .119 & .066 & .745 & .458 & .718 & $\begin{array}{r}1.39 \\
3\end{array}$ \\
\hline & $\begin{array}{l}\text { KUALITAS } \\
\text { PELAYANAN }\end{array}$ & .628 & .085 & .653 & $\begin{array}{r}7.37 \\
8\end{array}$ & .000 & .718 & $\begin{array}{r}1.39 \\
3\end{array}$ \\
\hline
\end{tabular}


a. Dependent Variable: KEPUTUSAN PEMBELIAN

Sumber: Data diolah, 2021

\section{H1 : Pengaruh bauran pemasaran terhadap keputusan pembelian produk pakaian}

Dari perhitungan table diatas nilai $t$ hitung $<\mathrm{t}$ table atau $0.745<1.98580$ yang berarti ditolak H0. Hasil pengujian secara parsial atau uji t 2 pihak dapat disimpulkan bahwa bauran pemasaran secara parsial tidak berpengaruh terhadap keputusan pembelian produk pakaian di Barata.

Berdasarkan hasil uji statistic t,diperoleh bahwa bauran pemasaran secara parsial tidak berpengaruh terhadap keputusan pembelian produk pakaian di Barata, dimana jika terjadi peningkatan atau penurunan bauran pemasaran maka tidak akan mempengaruhi keputusan pembelian produk pakaian di Barata. Hasil penelitian ini tidak sesuai dengan penelitian yang dilakukan oleh Hafifa Husna (2019) bahwa "Bauran pemasaran secara parsial berpengaruh signifikan dan positif terhadap keputusan pembelian pada Semoga Sukses Cell Pekanbaru".

\section{H2 :Pengaruh kualitas pelayanan terhadap keputusan pembelian produk pakaian}

Dari perhitungan table diatas nilai $\mathrm{t}$ hitung $>\mathrm{t}$ table atau $7.378>1,98580$ yang berarti diterima H0. Hasil pengujian secara parsial atau uji t 2 pihak dapat disimpulkan bahwa kualitas pelayanan secara parsial berpengaruh terhadap keputusan pembelian produk pakaian di Barata

Berdasarkan hasil uji statistic t,diperoleh bahwa kualitas pelayanan secara parsial berpengaruh terhadap keputusan pembelian produk pakaian di Barata, dimana jika terjadi peningkatan atau penurunan bauran pemasaran maka akan mempengaruhi keputusan pembelian produk pakaian di Barata. Hasil penelitian ini sesuai dengan penelitian yang dilakukan oleh Hafifa Husna (2019) bahwa "Kualitas pelayanan secara parsial berpengaruh signifikan dan positif terhadap keputusan pembelian pada Semoga Sukses Cell Pekanbaru".

Tabel 7. Uji F (Simultan)

\begin{tabular}{|c|c|c|c|c|c|c|}
\hline \multicolumn{7}{|c|}{ ANOVA $^{\mathrm{a}}$} \\
\hline \multicolumn{2}{|c|}{ Model } & Sum of & $\mathrm{df}$ & Mean & $\mathrm{F}$ & Sig. \\
\hline \multirow{3}{*}{1} & $\begin{array}{l}\text { Regressi } \\
\text { on }\end{array}$ & 6629.698 & 2 & 3314.849 & $\begin{array}{r}42.35 \\
9 \\
\end{array}$ & $.000^{\mathrm{b}}$ \\
\hline & Residual & 7277.792 & 93 & 78.256 & & \\
\hline & Total & 13907.490 & 95 & & & \\
\hline \multicolumn{7}{|c|}{ a. Dependent Variable: KEPUTUSAN PEMBELIAN } \\
\hline \multicolumn{7}{|c|}{ b. Predictors: (Constant), KUALITAS PELAYANAN, BAURAN } \\
\hline
\end{tabular}

Sumber: Data diolah, 2021

\section{H3 :Pengaruh pengaruh bauran pemasran dan kualitas pelayanan terhadap keputusan pembelian}

Dari perhitungan table diatas diperoleh nilai $\mathrm{F}$ hitung $>\mathrm{F}$ table atau $42.359>3.09$ yang berarti terima H0. Hasil pengujian secara simultan atau uji $\mathrm{F}$ dapat disimpulkan bahwa secara bersama-sama atau simultan bauran pemasaran dan kualitas pelayanan berpengaruh terhadap keputusan pembelian produk pakaian di Barata.

Berdasarkan hasil uji F,diperoleh bahwa secara bersama-sama atau simultan bauran pemasaran dan kualitas pelayanan berpengaruh terhadap keputusan pembelian produk pakaian di Barata, dimana jika terjadi peningkatan atau penurunan bauran pemasaran maka akan mempengaruhi keputusan pembelian produk pakaian di Barata. 
Hasil penelitian ini sesuai dengan penelitian yang dilakukan oleh Hafifa Husna (2019) bahwa "Berdasarkan hasil uji $\mathrm{F}$ secara simultan diketahui bahwa bauran pemasaran dan kualitas pelayanan memiliki pengaruh yang signifikan terhadap keputusan pembelian pada Semoga Sukses".

\section{KESIMPULAN}

Bauran pemasaran secara parsial tidak berpengaruh terhadap keputusan pembelian produk pakaian di Barata. Kualitas pelayanan secara parsial berpengaruh terhadap keputusan pembelian produk pakaian di Barata. Bauran pemasaran dan kualitas pelayanan secara simultan berpengaruh terhadap keputusan pembelian produk pakaian di Barata.

\section{REFERENSI}

Dewi, O. I., \& Sutanto, E. M. (2018). Pengaruh Bauran Pemasaran Terhadap Keputusan Pembelian Konsumen Chang Tea Di Surabaya. Agora.

Ghozali, I. (2013). Ghozali, Imam (2013). Aplikasi Analisis Multivariate Dengan Program IBM SPSS 21Update PLS Regresi. Semarang: Badan Penerbit Universitas Diponegoro.

PENGARUH BAURAN PEMASARAN DAN KUALITAS PELAYANAN TERHADAP KEPUTUSAN PEMBELIAN PRODUK MATAHARI DEPARTMEN STORE MEGA MALL MANADO. (2019). Jurnal EMBA: Jurnal Riset Ekonomi, Manajemen, Bisnis Dan Akuntansi. https://doi.org/10.35794/emba.v7i1.22384

PENGARUH BAURAN PEMASARAN TERHADAP VOLUME PENJUALAN PADA PT. TRIDJAYA MULIA SUKSES. (2017). Jurnal EMBA: Jurnal Riset Ekonomi, Manajemen, Bisnis Dan Akuntansi. https://doi.org/10.35794/emba.v5i3.17356

Sugiono, P. D. (2014). Metode penelitian pendidikan pendekatan kuantitatif.pdf. In Metode Penelitian Pendidikan Pendekatan Kuantitatif, Kualitatif Dan R\&D.

Sutrsino, N. A.-R. R. A., Widodo, J., \& Zulianto, M. (2018). PENGARUH BAURAN PEMASARAN TERHADAP KEPUTUSAN PEMBELIAN PRODUK RM AYAM BAKAR WONG SOLO JEMBER. JURNAL PENDIDIKAN EKONOMI: Jurnal Ilmiah Ilmu Pendidikan, Ilmu Ekonomi Dan Ilmu Sosial. https://doi.org/10.19184/jpe.v12i2.8568 